\title{
Bacterial biomass and cell size distributions in lakes: More and larger cells in anoxic waters
}

\author{
Jonathan J. Cole, Michael L. Pace, Nina F. Caraco, and \\ Gail S. Steinhart \\ Institute of Ecosystem Studies, Cary Arboretum, Millbrook, New York 12545
}

\begin{abstract}
We measured bacterial abundance, cell size distribution, and related microbiological and geochemical parametcrs in 20 stratified lakes from threc regions in the U.S. Both largest cell size and greatest bacterial abundance occurred in anoxic waters. Bacterial size distributions from the hypolimnia of lakes that were oxic were identical to those in surface waters. Bacteria from anoxic hypolimnia were 2-10 times larger than those from oxic water and cell size was independent of temperature under either oxic or anoxic conditions. For all lakes and strata, bacterial abundance was strongly related to the concentration of total phosphorus (TP). Cell size was not related to TP or to bacterial abundance, suggesting that abundance and size may be regulated by different processes. Bacterial biomass (calculated from the product of mean cell size and bacterial abundance) was typically 4 times greater in anoxic than in oxic waters of lakes.
\end{abstract}

The abundance, size, and biomass of bacteria are important variables in aquatic ecosystems. The quantity of carbon, nitrogen, and phosphorus in bacteria can be a significant fraction of the total in oceanic (Fuhrman et al. 1989) and lake (Cole and Caraco 1993) water columns. Bacteria can account for a substantial fraction of the cycling of $\mathrm{C}$ and other elements. In addition, bacteria may be an important resource for protozoans in pelagic food webs (e.g. Sherr and Sherr 1988). Where comparative studies have been conducted, bacterial abundance has been shown to be related to phytoplankton biomass as measured by chlorophyll (Bird and Kalff 1984; Cole et al. 1988) or total P (TP) (Currie 1990). One remarkable feature of these comparisons is that over a wide spectrum of ecosystem conditions bacterial abundance varies by only onc to two orders of magnitude. In contrast, phytoplankton and zooplankton biomass vary by more than three orders of magnitude over similarly large gradients (e.g. Hobbie and Cole 1984; Cole et al. 1988; McCauley and Kalff 1981).

Bacterial biomass is not usually measured directly. Rather, bacteria are counted, cell vol-

\footnotetext{
Acknowledgments

This study was supported by the National Science Foundation (BSR 89-17962 and BSR 90-19873) and is a contribution to the Institute of Ecosystem Studies.

We thank the researchers of the NTL-LTER for assistance with sampling and for use of some unpublished chemical data.
}

umes are estimated, and the product of these quantities is used to calculate biomass. Thus, one can consider bacterial biomass ( $\mu \mathrm{g} \mathrm{C} \mathrm{li-}$ ter $^{-1}$ ) as containing an "abundance" component and a "size" component. Most comparative work has focused on abundance. Where size has been considered, it has been noted that size varies either inversely or independently of trophic conditions (Van Es and Meyer-Reil 1982; Bird and Kalff 1984). Based on a recent intercomparison of cell size measurements, it would appear that much of the reported variation in size is related to methodology which varies among investigators. This variation seriously compromises quantitative comparison of cell size from published studies (H. Ducklow pers. comm.).

A further limitation of earlier comparative studies of bacteria has been that the data were primarily derived from the surface mixed layer (e.g. Bird and Kalff 1984; Cole et al. 1988) despite the strong physical and chemical gradients that occur in stratified water columns and strongly influence microbial activity. In this study we measured bacterial abundance and cell size distributions and computed biomass in the water columns of 20 lakes.

\section{Methods}

Samples for bacteria were taken at several depths in the epilimnia, metalimnia, and hypolimnia of 20 lakes during summer stratification (Table 1). For the majority of the lakes, samples were taken by peristaltic pump; in a 
Table 1. Lakes sampled in this study, grouped by location.

\begin{tabular}{|c|c|c|c|}
\hline \multirow[b]{2}{*}{ Lake } & \multicolumn{2}{|c|}{ Temp. $\left({ }^{\circ} \mathrm{C}\right)$} & \multirow{2}{*}{$\begin{array}{l}\text { Hypolimnctic } \mathrm{O}_{2} \\
(\text { mg liter ') }\end{array}$} \\
\hline & Surface & Hypolimnion & \\
\hline \multicolumn{4}{|c|}{ Northern Wisconsin LTER* lakes (Aug-Sep 90) } \\
\hline Allequash & 21 & 15.4 & $<0.3$ \\
\hline Big Musky & 21 & 9.7 & $<0.2$ \\
\hline Crystal & 25 & 8.3 & 4.8 \\
\hline Crystal Bog & 23.4 & 22.2 & 4.8 \\
\hline Sparkling & 21.1 & 6.2 & $<0.4$ \\
\hline Trout & 20.9 & 8.7 & $<0.4$ \\
\hline Trout Bog & 20.0 & 4.2 & $<0.4$ \\
\hline \multicolumn{4}{|c|}{$\begin{array}{c}\text { Michigan Upper Peninsula UNDERC } † \text { lakes } \\
\text { (Aug-Sep 90) }\end{array}$} \\
\hline Paul & 22.7 & 5.5 & 0 \\
\hline Peter & 23.5 & 4.6 & 0 \\
\hline Tuesday & 20.5 & 4.1 & 0 \\
\hline \multicolumn{4}{|c|}{$\begin{array}{c}\text { New York, Connecticut, New Hampshire, Pennsylvania } \\
\text { lakes (Aug-Sep 90) }\end{array}$} \\
\hline Ellsworth (NH) & 20.2 & 8.5 & $<0.1$ \\
\hline East Twin (CT) & 22.2 & 6.6 & $<0.1$ \\
\hline Lacawac (PA) & 25.2 & 7.4 & $<0.1$ \\
\hline Minnewaska (NY) & 19.2 & 8.7 & 4.3 \\
\hline Mohonk (NY) & 18.8 & 6.4 & $<0.1$ \\
\hline Pout Pond (NH) & 23.5 & 4.6 & $<0.1$ \\
\hline Stissing (NY) & 17.4 & 10.8 & $<0.1$ \\
\hline Upton (NY) & 18.2 & 5.0 & $<0.1$ \\
\hline \multicolumn{4}{|c|}{ Central Florida lakes (Oct 90) } \\
\hline Glenada & 27.5 & 25.2 & $<0.1$ \\
\hline Kingsley & 26.1 & 25.2 & 5.7 \\
\hline
\end{tabular}

* Long-term ecological rescarch, a program of NSF.

† University of Notre Dame Environmental Research Center.

few cases Van Dorn samplers were used. Subsamples were taken into scintillation vials and preserved with buffered Formalin ( $2 \% \mathrm{vol} / \mathrm{vol}$ final concn). Within $24 \mathrm{~h}$, samples were stained with acridine orange and passed through Irgalan-black-stained $0.2-\mu \mathrm{m}$ pore-size Nuclepore filters according to Hobbie et al. (1977). Samples were counted at $1,250 \times$ with an Olympus BHT microscope, and at least 10 fields of $>30$ bacteria per field were counted. For size measurements, samples were photographed at $838 \times$ with ASA 400 black-andwhite film (Kodak, TMAX). Setting the camera ASA at 1600 and increasing the development time to 21 min gave us sharp, high contrast images. The developed films were examined by image analysis (Olympus CUE2) using photographs of a stage micrometer for calibration. Photographic slides of bacteria were magnified with a macrolens attached to a video camera and projected to the image analyzer. One hundred individual cells per sample were digitized and area and perimeter recorded. The smallest bacteria occupied 8-9 pixels and the largest bacteria occupied $>1,000$ pixels. Volume was calculated with the formula of Bjørnsen (1986).

For each sampling, depth profiles of temperature and oxygen (YSI model 57) were taken as well as samples for water chemistry. Water samples were taken by peristaltic pump (sample contacts no metal). Unfiltered samples were used to measure TP. Separate, unfiltered samples were taken for the analysis of sulfate, sulfide, dissolved inorganic $\mathrm{C}$, and methane. For dissolved constituents, water was pumped through in-line GF/F filters (to prevent oxidation during filtration) directly into polypropylene bottles and acidified with sulfuric acid to $\mathrm{pH}<2$ pending analysis. Soluble reactive phosphate was measured spectrophotometrically; ammonium and nitrate were measured with a colorimetric method modified for the autoanalyzer. Details of the specific chemical analysis are reported elsewhere (Caraco et al. 1991).

\section{Results}

Bacterial cell size - We observed striking differences in the sizes of bacteria across lakes and depths. Although the mean cell size for the entire data set was $\sim 0.03 \mu \mathrm{m}^{3}( \pm 0.028$ $\mu \mathrm{m}^{3} \mathrm{SD}$ ), cell size ranged $\sim 20$-fold, from 0.01 to $0.2 \mu \mathrm{m}^{3}$. Cells from anoxic environments were consistently larger than those from oxic environments (Fig. 1). Larger cell size at depth was not found in thermally stratified lakes that had oxic hypolimnia (Fig. 1). Further, when our middepth samples were from oxic water, cell size distributions were like those of the epilimnion. When the middepth sample was anoxic, average cells were larger and distributions resembled those of anoxic bottom waters. The greater mean cell size in anoxic environments was not a consequence of a few larger cells. Rather, cells were uniformly larger across most or much of the size distribution (Fig. 1).

The mean bacterial cell size we observed $\left(0.03 \mu \mathrm{m}^{3}\right)$ is considerably smaller than that reported in some studies (e.g. Bell and $\mathrm{Ku}$ parinen 1984) but agrees well with others (e.g. Coffin and Sharp 1987). It is likely that much of the reported variation in cell size is the result of methodological differences in size measurements. This large between-investigator variation suggests that an estimate of the absolute sizes of pelagic bacteria remains problematic 


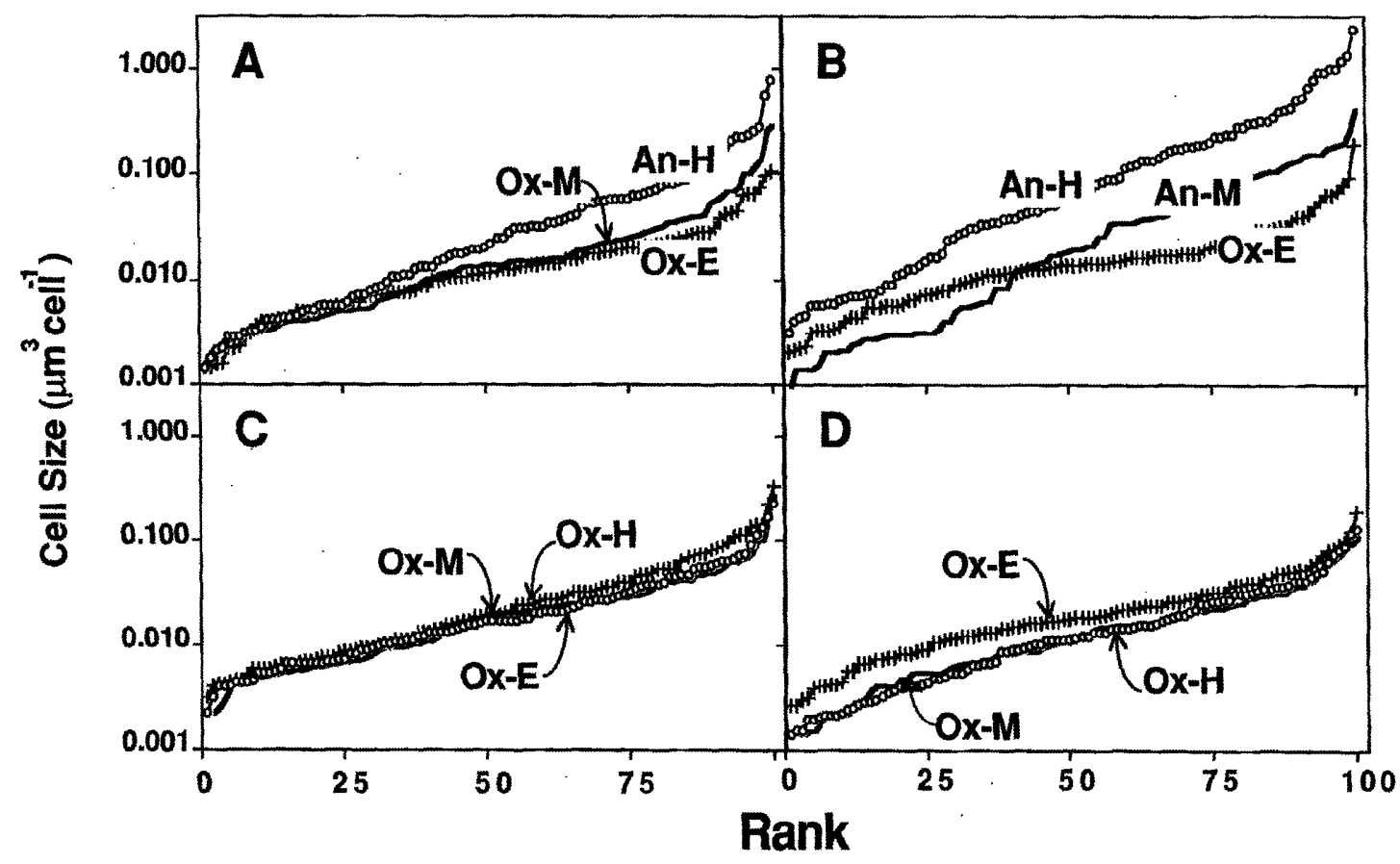

Fig. 1. Examples of bacterial cell size distributions from three depth strata of four lakes. Shown are the measured sizes of 100 cells ordered by rank from the smallest to the largest. E-cpilimnetic water (crossed line); $M$-metalimnetic water (bold line); H-hypolimnetic water (circled line); Ox-stratum was oxic; An-stratum was anoxic. In Sparkling Lake (A) the metalimnetic sample came from oxic water and the hypolimnetic sample from anoxic water. In East Twin Lake (B) both samples were from anoxic water. The hypolimnia of Kingsley Lake (C) and Crystal Lake (D) were oxic (see Table I).

and uncertain. In this study, because we used a single method throughout, our results concerning relative sizes of bacteria are quite robust even if there is uncertainty about absolute sizes.

We divided the entire data set (67 samples) into oxic ( $>0.5 \mathrm{mg} \mathrm{O}_{2}$ liter $\left.^{-1} ; N=40\right)$ and anoxic $\left(<0.5 \mathrm{mg} \mathrm{O}_{2}\right.$ liter $\left.^{-1} ; N=27\right)$ samples and found highly significant differences in mean cell size $(t$-test; $P<0.00001)$. On average, bacteria from anoxic lake water were about twice as large as those from oxic waters (Fig. 2).

Bacterial abundance-The number of bacteria also varied substantially across lakes and depths, from $1.1 \times 10^{9}$ to $2.2 \times 10^{10}$ cells/ liter $^{-1}$ (again $\sim 20$-fold). Like cell size, abundance was greatest in anoxic samples. The absence of oxygen was significantly related to greater bacterial abundance $(t$-test; $P<$ $0.00001)$. Bacteria were also roughly twice as abundant in anoxic waters as in oxic waters (Fig. 2).

Bacterial biomass-To calculate bacterial biomass we multiplied average cell volume by bacterial abundance to obtain the total bacterial volume per liter of water. We then multiplied total volume by an assumed bacterial

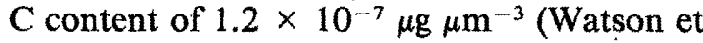
al. 1977) - a conservative estimate of biomass. Bacterial biomass in our data set averaged 28 $\mu \mathrm{g} \mathrm{C}$ liter ${ }^{-1}$ and ranged from 3 to $235 \mu \mathrm{g} \mathrm{C}$ liter ${ }^{-1}$ across lakes and depths. Average biomass in all oxic samples was $12.5( \pm 3.6 ; 95 \%$ C.I.) $\mu \mathrm{g} \mathrm{C}$ liter ${ }^{-1}$, whereas average biomass in all anoxic samples was $50( \pm 12.6 ; 95 \%$ C.I. $)$ $\mu \mathrm{g} \mathrm{Cliter}{ }^{-1}$ (Fig. 2). This 4-fold greater average bacterial biomass in the anoxic over oxic samples is due to the doubling of each of the components (cell size and abundance) that comprise calculated biomass (Fig. 2).

Relationships with oxygen and nutrients and temperature-All three parameters of interest (size, abundance, calculated biomass) were significantly and negatively related to dissolved oxygen (negatively; $P<0.05$ in all cases) and responded positively to elevated nutrient concentrations $\left(\mathrm{PO}_{4}, P<0.01\right.$ in all three cases; $\mathrm{NH}_{4}, P<0.01$ in all three cases). Because 


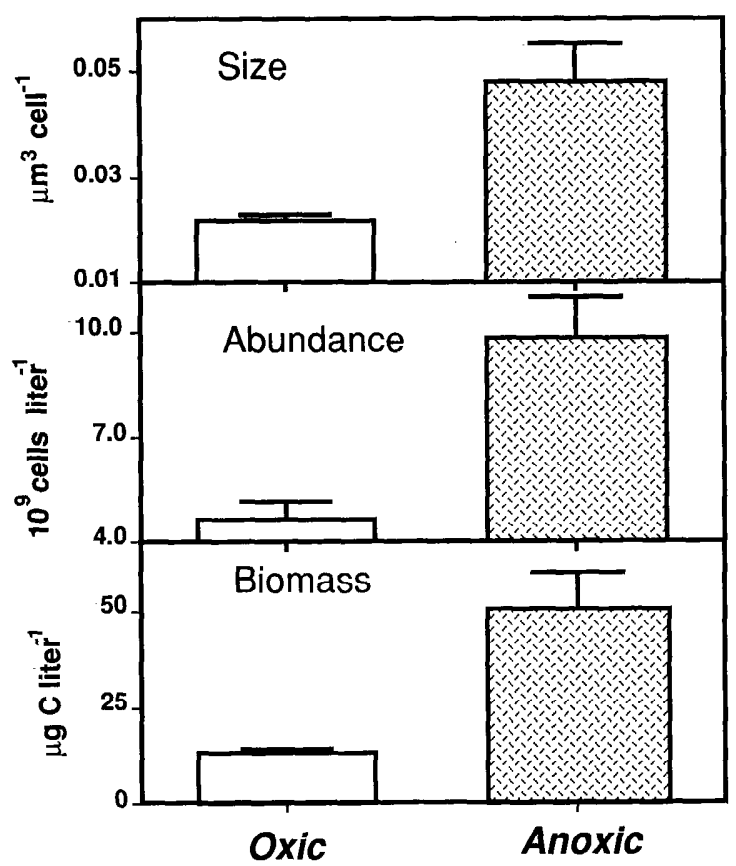

Fig. 2. Bacterial cell size, abundance, and biomass separated into samples from oxic and anoxic water. Shown are the means and $95 \%$ C.I. for each parameter. Twenty different lakes were sampled; 40 samples came from oxic water and 27 from anoxic water. For each parameter, the difference between oxic and anoxic environments is significant at $P<0.001(t$-test $)$.

dissolved oxygen, $\mathrm{PO}_{4}$, and $\mathrm{NH}_{4}$ were all highly cross-correlated, we cannot separately evaluate the effects of anoxia and elevated nutrients on biomass, numbers, or cell size. None of the three parameters were related to water temperature $(P>0.05$ in all cases), showing that increased size and abundance is not brought about simply by cooler hypolimnetic temperatures. Bacterial size and abundance were not related to each other $(P>0.05 ; r=$ $-0.13)$. Further, although both abundance and biomass $\left(\mu \mathrm{g} \mathrm{C}\right.$ liter $\left.^{-1}\right)$ were highly correlated to TP $(P<0.00001 ; r>0.5$ in both cascs), cell size was not correlated to TP. The differing responses of cell size and abundance suggest that they may be regulated by different factors.

Across both oxic and anoxic samples, computed bacterial biomass was positively related to the concentration of both $\mathrm{N}$ and $\mathrm{P}$. The relationship between $\log (\mathrm{TP})$ and $\log$ (bacterial biomass) is highly significant $(P<0.00001)$ and accounts for more than half of the variation in $\log$ (bacterial biomass) $\left(r^{2}=0.57\right.$; Fig.
3). This relationship is not an autocorrelation resulting from the $P$ contained in bacterial cells. We estimated the $\mathbf{P}$ content of bacterial cells by assuming a bacterial $C: P$ ratio of $50: 1$ (twice the $\mathrm{P}: \mathrm{C}$ content in the Redfield ratio; a conservative estimate from Vadstein et al. 1988). In agreement with arguments of Cole and Caraco (1993), the percent of TP in bacterial cells was a strong, negative function of the TP concentration (Fig. 4) and cannot explain the positive relationship in Fig. 3 .

Intriguingly, in the most dilute surface waters in our data set, bacterial cells could account for $30 \%$ of the TP in the system. In P-rich hypolimnetic samples, however, bacterial cells accounted for a trivial fraction $(<1 \%)$ of TP (Fig. 3). Had we chosen a less conservative value for the carbon-to-volume ratio of bacteria (e.g. Bratbak 1985) or a less conservative estimate of the bacterial $\mathrm{P}: \mathrm{C}$ ratio (4× Redfield; Vadstein et al. 1988), the pattern would be unchanged but bacteria could comprise an even larger fraction of the TP (up to $90 \%$ ) in oligotrophic environments.

\section{Discussion}

We observed greater bacterial biomass in the anoxic hypolimnia of lakes than in oxic surface waters. Although this phenomenon has not been previously analyzed, it has been noted in other systems. For two brackish systems in northern Europe, Fenchel et al. (1990) and Gast and Gockc (1988) reported larger cells and greatest bacterial biomass in anoxic water. For two freshwater lakes in North America, Ochs (1991) and Lovell and Konopka (1985) observed a similar trend.

Bacterial biomass is the product of two terms, cell size and cell abundance, that may be regulated somewhat independently in aquatic ecosystems. For example, our study shows that cell numbers and biomass (calculated from cell numbers and cell size) are well correlated to TP but cell size is not. Further, although cell size and cell abundance are roughly twice as large in anoxic as in oxic waters, there is no relationship between cell size and cell numbers. Within oxic waters, mean cell size is small and appears to be rather tightly constrained, and large cells are uncommon. In this regard, Hobbie and Cole (1984) saw large increases in cell abundance when oxic coastal water was experimentally eutrophicated; they did not report major changes in cell sizes. In anoxic wa- 


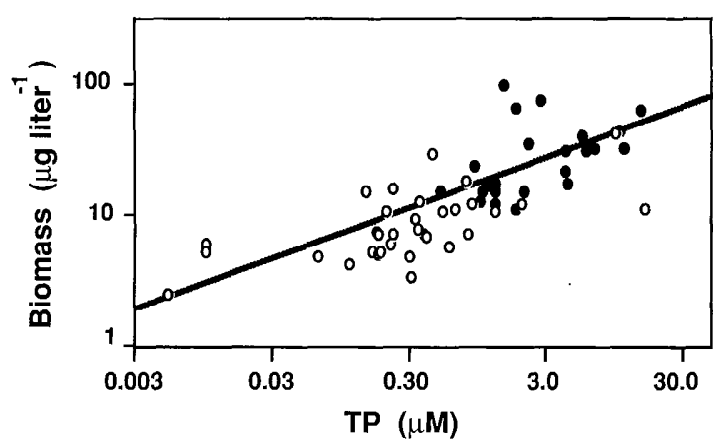

Fig. 3. Relationship between calculated bacterial biomass and TP across lakes and depth, both on log scales. The cquation for the line is $\log$ (biomass) $=1.32+0.375$ $\times \log (\mathrm{TP})$, which is significant $(P<0.00001)$ and explains $57 \%$ of the variation in calculated biomass. Samples from oxic environments-O; samples from anoxic environments-0. Bacterial biomass was calculated from measurements of cell abundance and volume.

ters, cells are larger on average and the variance in size is also greater.

Larger cell size in anoxic hypolimnia could have several explanations. These include species shifts, reduced respiratory metabolism in cooler water, reduced predation on larger cells, or greater availability of nutrients and organic substrates for growth. Our data set can address only some of these possibilities. Temperature is clearly not a dominant factor. In cold but oxic hypolimnia, bacteria are not larger (e.g. Crystal Lake; Fig. 1). In warm but anoxic hypolimnia, bacteria are large (e.g. Lake Glenada; Table 1). Further, the correlation between cell size and temperature is not significant. Anoxic hypolimnia are usually rich in organic and inorganic nutrients that may promote larger cell size. The significant correlations between cell size and either phosphate or ammonium are consistent with this argument. The concentrations of phosphate and ammonium are a consequence, in part, of the same processes that deplete oxygen (e.g. Caraco et al. 1991); thus, we cannot distinguish between anoxia and nutrient richness as determinants of cell size with the present data set alone.

Clearly the physiology and genetic composition of some of the anaerobic taxa is different from that of the aerobes. We know of no evidence that suggests that heterotrophic anaerobic bacterial groups such as sulfate reducers, denitrifiers, or fermentative bacteria are different in size from their aerobic counterparts.

It is possible, however, that autotrophic bac-

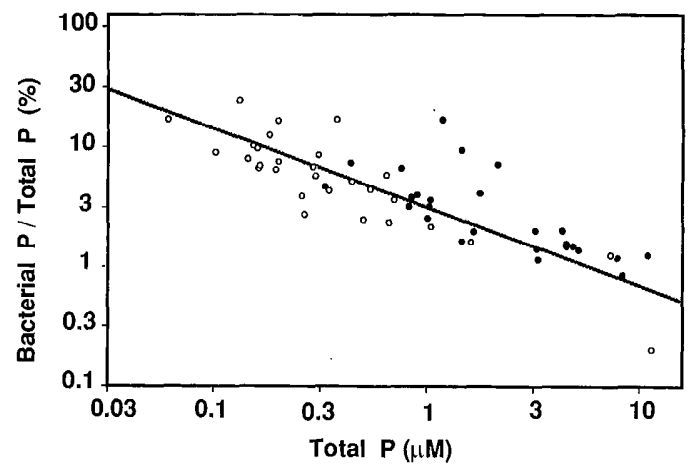

Fig. 4. Relationship between TP and the amount of $P$ estimated to be in bacterial cells across lakes and depths. Samples from oxic water-O; samples from anoxic water-0. Note log scales. The equation for the line is $\log [$ (bacterial P/TP) $\times 100 \%]=-0.62 \times \log (\mathrm{TP})+0.54$. The regression is significant $(P<0.001)$ and explains $65 \%$ of the variation in $\log ($ bacterial $\mathrm{P} / \mathrm{TP})$. Bacterial $\mathrm{P}$ was calculated from measurements of cell abundance, cell size, and assumed values for $\mathrm{C}$ content and $\mathrm{C}: \mathrm{P}$ ratio (see text).

teria contribute to the greater cell size we observed at depth. Although we cannot rule out this possibility with certainty, the depth distributions argue against it. The most abundant chemoautotrophs (nitrifiers and S-oxidizers) use oxygen as an electron acceptor and usually occur in a rclatively narrow plate near the interface between oxic and anoxic conditions. We did not observe narrow plates of abundant or large bacteria. Rather, biomass was usually greatest deep in the anoxic layer, well away from the oxycline. Similarly, photosynthetic bacteria are usually found near the top of the anoxic layer where light penetration is sufficient. Also, photosynthetic bacteria are often larger than the largest bacteria we measured. The Thiopedia from Zaca Lake, California, averaged $8 \mu \mathrm{m}^{3}$ per cell (Folt et al. 1989); Lamprocystis from Deadmoose Lake, Saskatchewan, ranged from 10 to $15 \mu \mathrm{m}^{3}$ per cell (Parker and Hammer 1983). The largest bacteria we counted were almost two orders of magnitude smaller than these.

Predators of bacteria may be less abundant and less active in anoxic waters. Clearly metazoan predators, such as cladocerans, are virtually absent from anoxic waters, although there are some reports of diel crustacean migrations below the oxycline (Culver and Brunskill 1969). Although specialized protozoa inhabit anoxic environments, abundances are typically low (Fenchel et al. 1990). Bacteria 
probably experience lower rates of predation in anoxic water and larger cells may not be eliminated as effectively as they are in surface waters. These observations are consistent with predator control of cell size distribution and provide a possible explanation for the larger cells observed in anoxic hypolimnia.

Our study leaves some intriguing questions unanswered. For example, what sets the upper limit for pelagic bacterial cell size in aquatic ecosystems? Bacteria that reach sizes of 0.5 $\mu \mathrm{m}^{3}$ (5-10 times the average we observed in the field even under anoxic conditions) are easy to culture, without enrichment, from lake water. Do bacterial cell size distributions respond to food-web manipulations that alter predation pressure, and at what time scale? In oligotrophic environments, planktonic bacteria conservatively account for $\sim 30 \%$ of the TP (possibly more if a higher bacterial $\mathrm{P}: \mathrm{C}$ ratio is assumed; see Vadstein et al. 1988). Does this large bacterial reservoir of a limiting nutrient for phytoplankton prevent further growth of phytoplankton in oligotrophic lakes?

\section{References}

Bell, R. T., and J. Kupakinen. 1984. Assessing phytoplankton and bacterioplankton production during early spring in Lake Erken, Sweden. Appl. Environ. Microbiol. 48: 1221-1230.

BIRD, D. F., AND J. KALFF. 1984. Empirical relationships between bacterial abundance and chlorophyll concentration in fresh and marine waters. Can. J. Fish. Aquat. Sci. 41: 1015-1023.

BJøRNSEN, P. K. 1986. Bacterioplankton growth yield in continuous seawater cultures. Mar. Ecol. Prog. Ser. 30: $191-196$.

BratbaK, G. 1985. Bacterial biovolume and biomass estimated. Appl. Environ. Microbiol. 49: 1488-1493.

Caraco, N. F., J. J. Cole, and G. E. Likens. 1991. A cross-system study of phosphorus release from lake sediments, p. 241-258. In J. J. Cole et al. [eds.], Comparative analyses of ecosystems: Patterns, mechanisms and theories. Springer.

Coffin, R. B., AND J. H. Sharp. 1987. Microbial trophodynamics in the Delaware estuary. Mar. Ecol. Prog. Ser. 17: 15-24.

Cole, J. J., and N. F. Caraco. 1993. The pelagic microbial food web of oligotrophic lakes, p. 101-111. In T. E. Ford [ed.], Aquatic microbiology. Blackwell. , S. Findlay, AND M. L. PACE. 1988. Bacterial production in fresh and saltwater ecosystems: A crosssystem overview. Mar. Ecol. Prog. Ser. 43: 1-10.
Culver, D. A., AND G. J. Brunskill. 1969. Fayetteville Green Lake, New York. 5. Studies of primary production and zooplankton in a meromictic marl lake. Limnol. Oceanogr. 14: 862-873.

Currie, D. J. 1990. Large scale variability and interactions among phytoplankton, bacterioplankton, and phosphorus. Limnol. Oceanogr. 35: 1437-1455.

FenChel, T., L. D. KRISTENSEN, AND L. Rasmussen. 1990. Water-column anoxia: Vertical zonation of planktonic protozoa. Mar. Ecol. Prog. Ser. 62: 1-10.

Folt, C., M. J. WeVers, M. P. Yoder-Williams, AND R. HowMILLER. 1989. Field study comparing growth and viability of a population of phototrophic bacteria. Appl. Environ. Microbiol. 55: 78-85.

Fuhrman, J. A., T. D. Sleeter, C. A. Carlson, and L. M. Proctor. 1989. Dominance of bacterial biomass in the Sargasso Sea and its ecological implications. Mar. Ecol. Prog. Ser. 57: 207-217.

GAST, V., AND K. Gocke. 1988. Vertical distribution of number, biomass and size-class spectrum of bacteria in relation to oxic/anoxic conditions in the central Baltic Sea. Mar. Ecol. Prog. Ser. 45: 179-186.

HobBiE, J. E., AND J. J. Cole. 1984. Response of a detrital foodweb to eutrophication. Bull. Mar. Sci. 35: 357363.

- R. J. DALEY, AND S. JASPER. 1977. Use of Nuclepore filters for counting bacteria by fluorescence microscopy. Appl. Environ. Microbiol. 22: 1225-1228.

Lovell, C. R., AND A. Konopka. 1985. Primary and bacterial production in two dimictic Indiana lakes. Appl. Environ. Microbiol. 49: 485-491.

MCCAULEY, E., AND J. KALFF. 1981. Empirical relationships between phytoplankton and zooplankton biomass in lakes. Can. J. Fish. Aquat. Sci. 38: 458-463.

Ochs, C. 1991. Population ecology of the planktonic bacteria of Mirror Lake, New Hampshire. Ph.D. thesis, Cornell Univ. 225 p.

Parker, R. D., AND U. T. HAmmer. 1983. A study of the chromatiacea in a saline meromictic lake in Saskatchewan, Canada. Int. Rev. Gesamten Hydrol. 68: 839-851.

Sherr, E., ANd B. Sherr. 1988. Role of microbes in pelagic food webs: A revised concept. Limnol. Oceanogr. 33: 1225-1226.

Vadstein, O., A. Jensen, Y. Olsen, And H. Reinertsen. 1988. Growth and phosphorus status of limnetic phytoplankton and bacteria. Limnol. Oceanogr. 33: 489-503.

Van Es, F. B., AND L. A. Meyer-Reil. 1982. Biomass and metabolic activity of heterotrophic marine bacteria. Adv. Microb. Ecol. 6: 111-170.

Watson, S. W., T. J. Novitsky, H. L. Quincy, and F. W. VALOIS. 1977. Determination of bacterial number and biomass in the marine environment. Appl. Environ. Microbiol. 33: 940-946.

Submitted: 7 July 1992 Accepted: 23 March 1993 Revised: 7 April 1993 